\title{
Comparative evaluation of russian black pied and holstein cattle breeds of foreign breeding
}

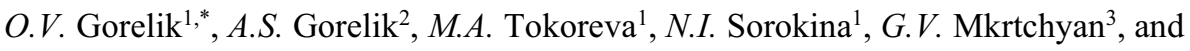 \\ O.M. Mukhtarova ${ }^{3}$ \\ ${ }^{1}$ Ural State Agricultural University, 42, Karl Liebknecht street, 620075 Yekaterinburg, Russian \\ Federation \\ ${ }^{2}$ Ural Institute of The state fire service of the EMERCOM of Russia, 22, Mira street, 620062 \\ Yekaterinburg, Russian Federation \\ ${ }^{3}$ Moscow State Academy of Veterinary Medicine and Biotechnology named after K.I. Skryabin, 23, \\ Academician Skryabin street, 109472 Moscow, Russian Federation
}

\begin{abstract}
A related Holstein breed has recently been used to improve domestic dairy cattle and create highly productive herds by purchasing semen from breeding bulls, as well as a large number of heifers and calves of foreign breeding. The purpose of the work is a comparative assessment of the productive qualities of Black Pied and Holstein cows of foreign breeding. Purebred Holstein cows differ from animals of Black Pied breed in milk yield per lactation by $1064 \mathrm{~kg}$ or $15.2 \%$ ( $\mathrm{P} \leq 0.01$, in favor of Holstein cows). In terms of quality indicators of milk, that are the content of fat and protein in milk, the superiority remained with Black Pied cows. The difference was significant at $\mathrm{P} \leq 0.05$ for fat content in milk and at $\mathrm{P} \leq 0.001$ for protein content. Both groups of cows exceeded the breed standard for milk yield per lactation, mass fraction of fat and mass fraction of protein in milk. The milk of the Russian Black Pied cattle contains more essential amino acids. The milk of cows of both breeds can be considered complete, since the amount of limited amino acids in the milk of purebred Holstein cows of foreign breeding is over $95 \%$ of their content in the ideal protein.
\end{abstract}

\section{Introduction}

Sustainable supply of the population with high-quality food, including milk, is the main necessity in ensuring the health of the nation and food security of any country [1-7]. Particular attention is paid to the development of dairy farming, since the main quantity of a valuable food product and raw material for the dairy industry, milk, is obtained from cattle, more than $99 \%$ of the total production. An increase in the productivity of cows is inseparably associated with an improvement in the quality of milk [8-18]. The main livestock of dairy cattle belongs to the Russian Black Pied breed, which has separate offsprings, differing in economic and biological characteristics. A related Holstein breed has recently been used to improve the Russian dairy cattle and create highly productive

* Corresponding author: olgao205en@yandex.ru 
herds by purchasing semen from breeding bulls, a large number of heifers and calves of foreign breeding. The widespread, long-term use of the valuable gene pool of foreign breeding Holstein bulls led to the creation of a large array of Holstein cattle in various climatic and ecological forage zones of the country, which also differs in economically useful and biological characteristics, which is due to the breed resources of cattle breeding zone and country of origin of seed bulls involved in crossing [19-21]. Purebred animals of the Holstein breed were used both for crossing with bulls of the Russian Black Pied breed, and were bred among "themselves" to obtain offspring adapted to local conditions [22-27]. A comparative study of the productive qualities of the Russian Black Pied cattle and Holstein animals of foreign selection is relevant and of practical importance.

The purpose of the work is a comparative assessment of the productive qualities of Black Pied and Holstein cows of foreign breeding for productive qualities.

\section{Materials and method}

The studies were carried out in an agricultural enterprise in the Chelyabinsk Region. Two groups of cows with the third lactation were selected for the research, taking into account the date of birth, date of calving, breed characteristics. The first group were cows of the Russian Black Pied breed, the second - Holstein cows of foreign breeding. Milk productivity was assessed by milk yield for 305 days of lactation using control milking once a month. The quality indicators of milk were investigated according to generally accepted methods. Mass fraction of fat and mass fraction of protein in milk were measured using "Klever 1M" device; the sanitary and hygienic indicators of milk were assessed; the coefficient of biological usefulness and biological efficiency of cows were calculated according to the method proposed by V.N. Lazarenko (1990) and O.V. Gorelik (1999); milkiness coefficient, amino acid score were studied.

\section{Results and Discussion}

The farm uses Holsteinized Black Pied cattle with a proportion of Holstein blood (more than $75 \%$ ) and purebred Holstein animals of foreign breeding.

Figure 1 shows the performance indicators of both breeds of cows.

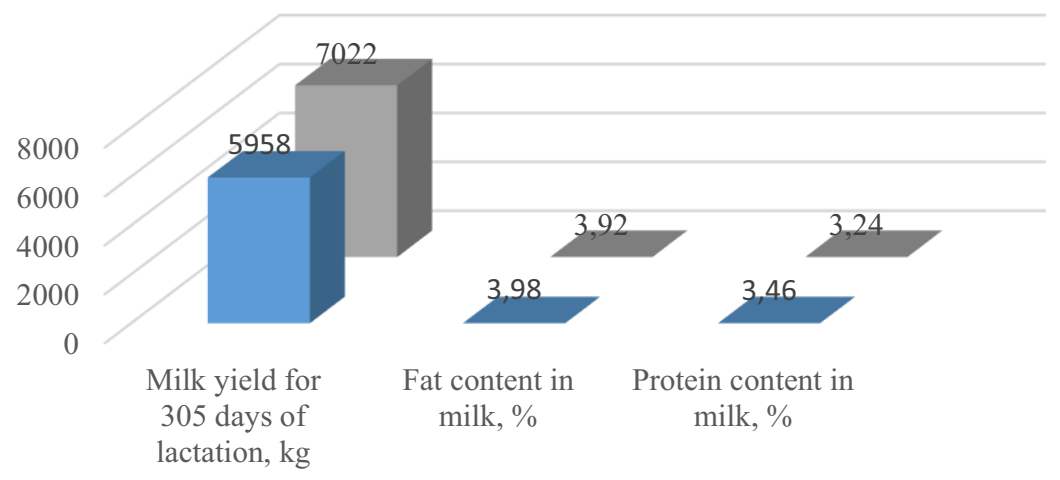

घlack-and-white breed $\quad$ Holstein breed

Fig. 1. Milk yield and quality milk indicators of cows of different breeds. 
The figure clearly shows that purebred Holstein cows differ from animals of the Black Pied breed in milk yield per lactation by $1064 \mathrm{~kg}$ or $15.2 \%(\mathrm{P} \leq 0.01$, in favor of Holstein cows). In terms of quality indicators of milk - the content of fat and protein in milk, the superiority remained with black-and-white cows. The difference was significant at $\mathrm{P} \leq 0.05$ for fat content in milk and at $\mathrm{P} \leq 0.001$ for protein content. Both groups of cows exceeded the breed standard for milk yield per lactation, mass fraction of fat and mass fraction of protein in milk.

When determining the breeding value of cows, such an indicator as the yield of milk fat is taken into account. We have calculated the indicators of the amount of milk fat, milk protein and dry matter obtained in milk during lactation (Figure 2).

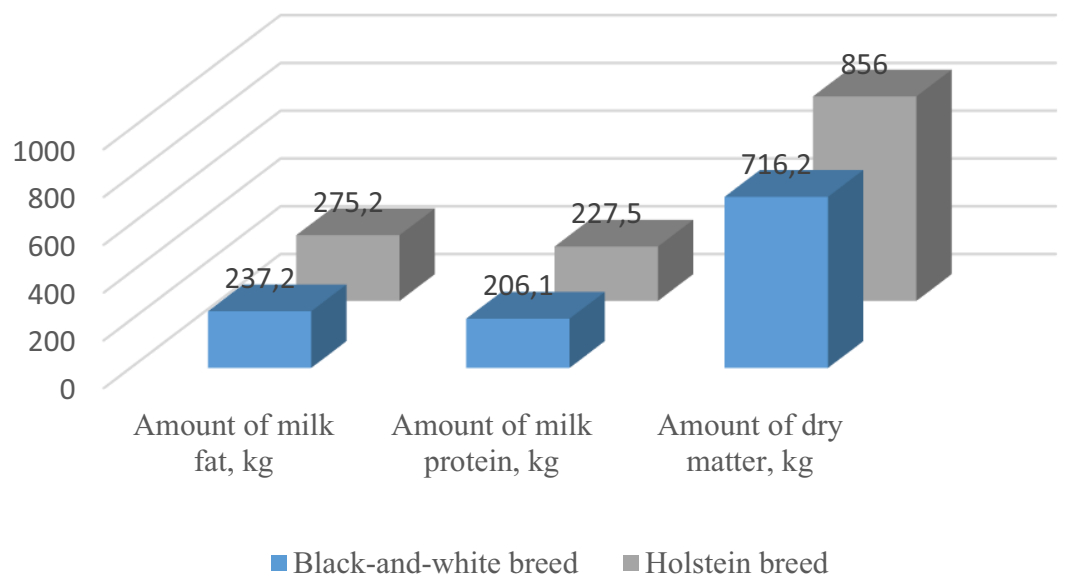

Fig. 2. The yield of nutrients in milk, $\mathrm{kg}$.

Despite the lower indicators of the mass fraction of fat and the mass fraction of protein in milk of Holstein cows, the yield of nutrients per lactation, including milk fat and milk protein, turned out to be significantly higher than in animals of the Russian Black Pied breed ( $\mathrm{P} \leq 0.05$ - $\mathrm{P} \leq 0.01$, respectively in terms of indicators). In general, milk nutrients from cows of both breeds were received 1.27 and 1.46 times more than their live weight. Based on the above stated, it can be concluded that the yield of nutrients in milk depends to a greater extent on milk yield per lactation and to a lesser extent on the quality indicators of milk, although they play a certain role.

The productive qualities of cows are also assessed using certain coefficients, such as milk production coefficient, cow biological efficiency (CBE), biological value coefficient (BVC) (Figure 3). 


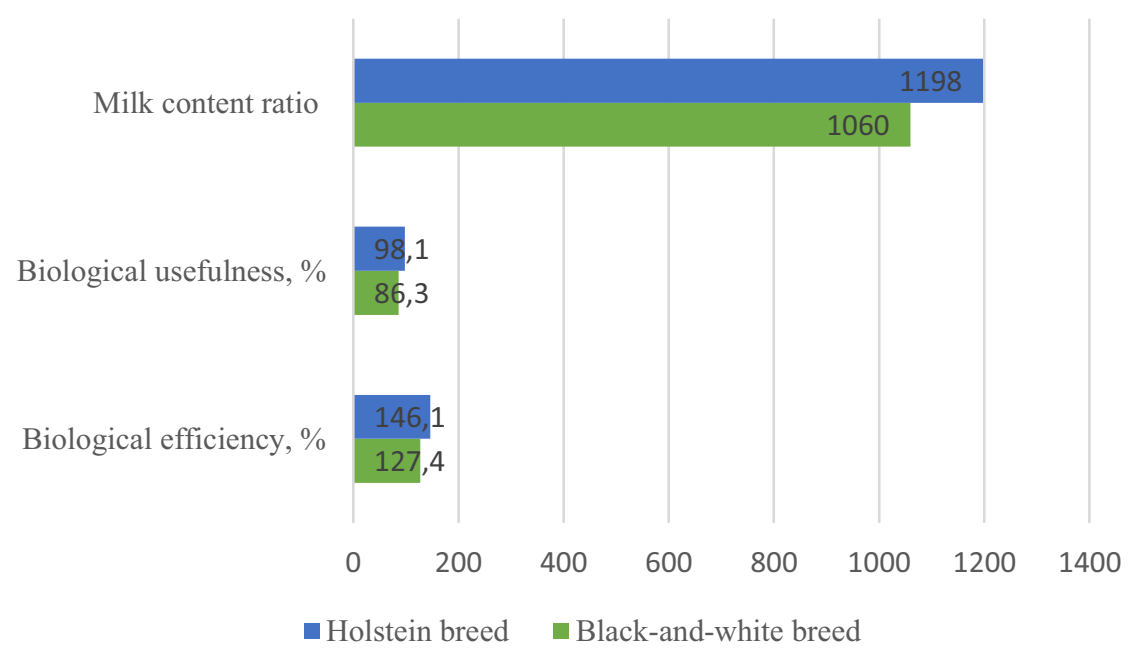

Fig. 3. Indicators of milk productivity.

As a result of the studies, it turned out that the Holstein cows were superior in productive qualities to the Holsteinized Black Pied cattle of domestic breeding.

Cows also differed in the quality and value of milk protein (Figure 4).

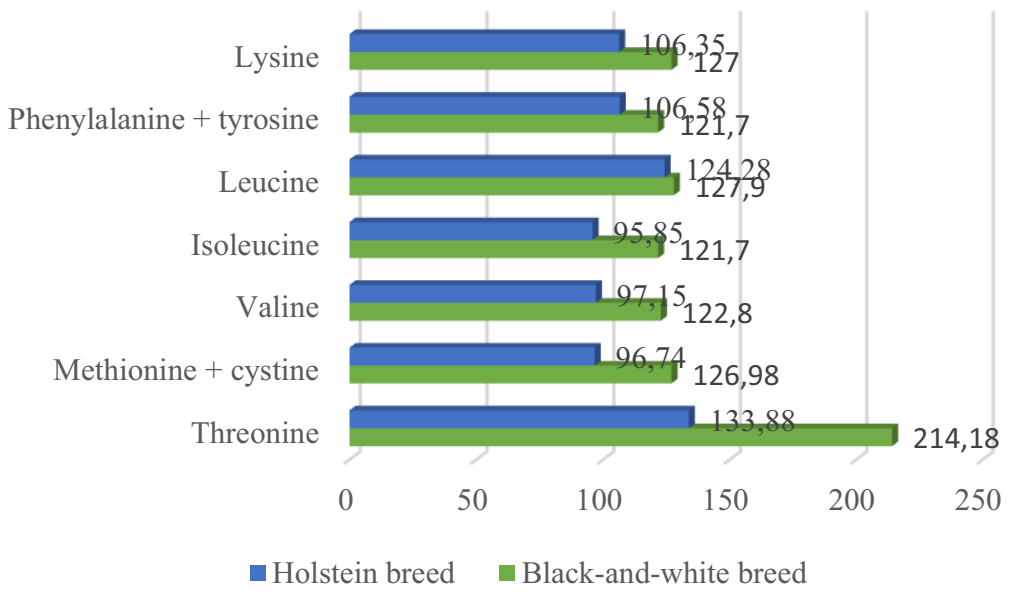

Fig. 4. The content of essential amino acids as a percentage of the ideal protein, $\%$.

As a result of the studies and assessment of the amino acid score according to the usefulness of milk protein, it was found that the milk of the Russian Black Pied cattle contains more essential amino acids than milk from purebred Holstein cows, as can be judged from the figure. The percentage of individual amino acids exceeds that of an ideal protein. The milk of cows of both breeds can be considered complete, since the amount of limited amino acids in the milk of purebred Holstein cows of foreign breeding is over 95\% of their content in the ideal protein.

Similar data were obtained in the results of research by N.V. Bogolyubova, V.P. Korotky, A.S. Zenkin, V.A. Ryzhov, N.P. Buryakov [23,24], V. Mymrin and O.G. Loretts 
[21], O.V. Gorelik, O.E. Lihodeevskaya, N.N. Zezin, M.Ya. Sevostyanov and O.I. Leshonok [25-26].

\section{Conclusion}

Based on the above stated, it can be concluded that the breeding stock of both breeds have a high genetic potential for productivity. Animals of the Holstein breed of foreign selection surpass the cows of the Russian Black Pied breed in milk yield, but they are inferior in mass fraction of fat and mass fraction of protein in milk. The milk of the Russian Black Pied cattle contains more essential amino acids than milk from purebred Holstein cows.

\section{References}

1. O. Gorelik, M. Rebezov, A. Gorelik, S. Harlap, I. Dolmatova, T. Zaitseva, N. Maksimuk, N. Fedoseeva, N. Novikova, International Journal of Innovative Technology and Exploring Engineering 8(7), 559-62 (2019)

2. O. Gorelik et al., International Journal of Pharmaceutical Research (2019) Doi: 10.31838/ijpr/2019.11.01.133

3. O. Gorelik et al., Annual Research \& Review in Biology 18(4), 1-5 (2017) DOI: 10.9734/ARRB/2017/36937

4. A. Belookov, O. Belookova, V. Zhuravel, S. Gritsenko, I. Bobyleva, E. Ermolova, S. Ermolov, Y. Matrosova, M. Rebezov, E. Ponomarev, International Journal of Engineering and Advanced Technology 8(4), 1058-61 (2019)

5. F. Khaziakhmetov et al., Research Journal of Pharmaceutical, Biological and Chemical Sciences 9(3), 866-70 (2018) WOS:000438847100113

6. F. Khaziakhmetov, A. Khabirov, M. Rebezov, A. Basharov, I. Ziangulov, E. Okuskhanova, International Journal of Veterinary Science 7(4), 178-81 (2018)

7. A. Gorelik et al., Advances in Agricultural and Biological Sciences 2(1), 5-12 (2016)

8. O.V. Gorelik et al., Advances in Agricultural and Biological Sciences 2(1), 27-33 (2016)

9. F. Smolnikova, Z. Moldabayeva, M. Klychkova, O. Gorelik, R. Khaybrakhmanov, I. Mironova, A. Kalimullin, G. Latypova, International Journal of Innovative Technology and Exploring Engineering 8 (7), 670-72 (2019)

10. N. Chernopolskaya, N. Gavrilova, M. Rebezov, S. Harlap, A. Nigmatyanov, G. Peshcherov, T. Bychkova, K. Vlasova, I. Karapetyan, International Journal of Pharmaceutical Research 11(1), 545-50 (2019) DOI: 10.35940/ijrte.B3158.078219

11. N. Chernopolskaya, N. Gavrilova, M. Rebezov, I. Dolmatova, T. Zaitseva, Y. Somova, M. Babaeva, E. Ponomarev, O. Voskanyan, International Journal of Engineering and Advanced Technology 8(4), 40-45(2019) DOI: 10.35940/ijrte.B3158.078219

12. N. Gavrilova, N. Chernopolskaya, M. Rebezov, D. Moisejkina, I. Dolmatova, I. Mironova, G. Peshcherov, O. Gorelik, M. Derkho, International Journal of Recent Technology and Engineering 8(2,) 2718-22 (2019) DOI: 10.35940/ijrte.B3158.078219

13. N. Gavrilova, N. Chernopolskaya, M. Rebezov, E. Shchetinina, I. Suyazova, S. Safronov, V. Ivanova, E. Sultanova, Journal of Critical Reviews 7(4), 233-36 (2020) DOI: $10.31838 /$ jcr.07.04.43

14. M. Temerbayeva et al., Annual Research \& Review in Biology 23(6), 1-7 (2018) DOI: 
$10.9734 / \mathrm{arrb} / 2018 / 38800$

15. M. Temerbayeva et al., Research journal of pharmaceutical biological and chemical sciences 9 (1), 291-95 (2018)

16. A. Serikova, F. Smolnikova, M. Rebezov, E. Okuskhanova, M. Temerbayeva, O. Gorelik, S. Kharlap, Sh. Baitukenova, S. Baitukenova, Y. Tumbasova, Research Journal of Pharmaceutical, Biological and Chemical Sciences 9(4), 495-500 (2018) WOS:000438848100062

17. F. Smolnikova, S. Toleubekova, M. Temerbayeva, E. Cherkasova, O. Gorelik, S. Kharlap, M. Derkho, M. Rebezov, I. Penkova, Journal of Pharmaceutical, Biological and Chemical Sciences 9(3), 1003-08 (2018) WOS:000438847100131

18. N. Kuramshina, M. Rebezov, E. Kuramshin, L. Tretyak, G. Topuria, D. Kulikov, A. Evtushenko, S. Harlap, E. Okuskhanova, International Journal of Pharmaceutical Research 11(1), 1301-05 (2019) DOI: 10.21668/health.risk/2019.2.04.eng

19. E. Skvortsov, O. Bykova, V. Mymrin, E. Skvortsova, O. Neverova, V. Nabokov and V. Kosilov, The Turkish Online Journal of Design Art and Communication 8(SMRCHSPCL) 291-99

20. V. Mymrin, O. Loretts, Contemporary trends in the formation of economicallybeneficial qualities in productive animals. Digital agriculture - development strategy Proceedings of the International Scientific and Practical Conference(ISPC 2019) Advances in Intelligent Systems Research 511-514 (2019)

21. S. Gridina, V. Gridin, O. Leshonok, Advances in Engineering Research, 253-256 (2018)

22. N. Bogolyubova, V. Korotky, A. Zenkin, V. Ryzhov, N. Buryakov, OnLine Journal of Biological Sciences 17(2), 121-27 (2017)

23. N. Bogolyubova, V. Romanov, V. Korotky, V. Ryzhov, A. Zenkin, Asian Journal of Pharmaceutical and Clinical Research 10(10), 117-20 (2017)

24. O.V. Gorelik et al., IOP Conf. Ser.: Earth Environ. Sci. 548, 082009 (2020) doi:10.1088/1755-1315/548/8/082009

25. O.V. Gorelik et al., IOP Conf. Ser.: Earth Environ. Sci. (2020) /10.1088/1755$1315 / 548 / 8 / 082013$

26. O. Gorelik et al., AIP Conference Proceedings 2207020012 (2020) doi $10.1063 / 5.0000317$

27. L.G. Levina, K.E. Tikhonov, O.A. Artemieva, M.V. Zelepukina, Agrarian Bulletin of the Urals, 02(193), 54-61 (2020) DOI: 10.32417/1997-4868-2020-193-2-54-61 (In Russian) 